\title{
Anti-protein-bound polysaccharide-K monoclonal antibody binds the active structure and neutralizes direct antitumor action of the compound
}

\author{
HIROTAKA HOSHI $^{1}$, HIKARU SAITO ${ }^{1}$, HIROKO IIJIMA ${ }^{1}$, MOTOYUKI UCHIDA ${ }^{1}$, TSUTOMU WADA ${ }^{1}$, \\ GENTARO ITO $^{2}$, HIROAKI TANAKA ${ }^{2}$, TETSUJI SAWADA ${ }^{2}$ and KOSEI HIRAKAWA ${ }^{2}$ \\ ${ }^{1}$ Biomedical Research Laboratories, Kureha Corp., 3-26-2, Hyakunin-cho, Shinjuku-ku, Tokyo 169-8503; \\ ${ }^{2}$ Department of Surgical Oncology, Osaka City University Graduate School of Medicine, \\ 1-4-3, Asahi-machi, Abeno-ku, Osaka 545-8585, Japan
}

Received September 27, 2010; Accepted November 26, 2010

DOI: $10.3892 /$ or.2011.1155

\begin{abstract}
Protein-bound polysaccharide K (PSK) is extracted and purified from Coriolus versicolor (CM101), and is used as an anti-cancer agent. In this study, focusing on the direct actions of PSK, we investigated whether PSK reaches tumor and immune tissues with its active structure remaining intact, and the direct action of PSK was evaluated by its antitumor effects against MethA fibrosarcomas implanted in immunodeficient NOD/SCID mice. The results obtained suggest that PSK reaches the tumor tissue in its active form and exhibits antitumor effects against MethA cells.
\end{abstract}

\section{Introduction}

Protein-bound polysaccharide-K (PSK) is a proteinpolysaccharide complex extracted from the cultured mycelia of Coriolus versicolor (strain CM101). In Japan, this compound is mainly used as an anti-cancer agent for postoperative gastric cancer and colorectal cancer in combination with chemotherapeutic agent. The molecular weight of PSK averages approximately 100,000, and varies over a wide range from 5,000 to 300,000 . The main structural constituent is polysaccharide with the main chain linked by $B-D-(1 \rightarrow 4)$ bond and the side chains by $\beta-D-(1 \rightarrow 3)$ and $B-D-(1 \rightarrow 6)$ bonds.

The antitumor effect of PSK is manifested by three major mechanisms of action: i) inhibition of cell proliferation (cytostatic effect); ii) neutralization of immunosuppressive substances; and iii) immunostimulatory activities (1-13).

Correspondence to: Dr Hirotaka Hoshi, Biomedical Research Laboratories, Kureha Corp., 3-26-2, Hyakunin-cho, Shinjuku-ku, Tokyo 169-8503, Japan

E-mail: h-hoshi@kureha.co.jp

Key words: protein-bound polysaccharide K, glucan, polysaccharide, Coriolus versicolor, monoclonal antibody
However, no data has hitherto demonstrated that the physiologically active structure of PSK is actually absorbed from bowel and reaches tumor and immune tissues. In addition, it remains unknown which moiety of the PSK molecule is responsible for these direct and indirect antitumor actions. One of the reasons is that PSK is not a compound with homogeneous structure, but is a mixture of glucan and protein complexes formed during the extraction process. Therefore isolation and structural determination of the active structure by conventional methods such as high performance liquid chromatography and mass spectral analysis are difficult. Furthermore, since the structure of its active site is unknown, there are difficulties in investigating the blood concentration and tumor tissue distribution of the compound after administration.

Methods for the detection of PSK include the Limulus test that detects B1-3 glucan or lipopolysaccharide (LPS) (unpublished data). However, since the Limulus test is positive not only for PSK but also for other polysaccharides containing B1-3 glucan (such as laminarin and yeast glucan), it is not a specific detection method for PSK (unpublished data). Production of antibodies against PSK and the evaluation of these antibodies have also been reported (14). However, the rabbit anti-PSK polyclonal antibodies produced recognize all molecules containing $\beta 1-3$ glucan, $\beta 1-4$ glucan and $B 1-6$ glucan structures, and is therefore relatively low specificity for PSK. These antibodies are not appropriate for the detection of PSK with physiological activities (unpublished data).

In the present study, we produced a monoclonal antibody against the active structure of PSK, and investigated whether PSK reaches tumor and other tissues with its active structure remaining intact.

\section{Materials and methods}

Animals experiment. All animal experiments were performed under the Institutional Guidelines for Care and Use of Laboratory Animals (Biomedical Research Laboratories, Kureha Corp.). The experimental protocol was approved by the Ethics Committee on Animal Experiments of the Biomedical Research Laboratories of Kureha Corp., and the 
mice were handled in accordance with the guidelines of the committee. Five-week-old female NOD/scid mice were purchased from Charles River Laboratories Japan, Inc. (Kanagawa, Japan), and used in experiments at the age of 6 weeks after acclimatization under specific pathogen-free conditions. The mice were allowed free access to CE-2 diet (Oriental Yeast, Tokyo, Japan) and sterilized tap water. They were housed in an animal room conditioned at $25 \pm 2{ }^{\circ} \mathrm{C}$, $55 \pm 7 \%$ humidity, laminar air flow and $12 \mathrm{~h}$ light/ $12 \mathrm{~h}$ dark cycle at 150-300 lux. To maintain a uniform environment, noise was carefully avoided, and only keepers and investigators were allowed into the animal room.

Materials. PSK (Kureha Corp., Tokyo, Japan) was dissolved in phosphate-buffered saline (PBS, $\mathrm{pH} 7.4)$. Cellulose [ $[3-$ $(1,4)$-D-glucan], laminarin [ $[3-(1,3)(1,6)-D$-glucan], glycogen $[\alpha-(1,4)$-D-glucan $]$, dextran $[\alpha-(1,6)-D$-glucan $]$ were purchased from Sigma-Aldrich Japan (Tokyo, Japan).

Cell culture conditions. P2/0-Ag14 myeloma cell line (SP2/ 0 cells), mink lung epithelial cell line (Mv1Lu) and MethA fibrosarcoma cell line were obtained from the American Type Culture Collection (Rockville, MD, USA). Mouse macrophagelike cell line (J774.1) was obtained from RIKEN Bioresource Center (Tsukuba, Japan). Mv1Lu cells were cultured in Dulbecco's modified Eagle's medium (DMEM; Invitrogen Corp., San Diego, CA) supplemented with $10 \%$ fetal bovine serum (FBS; Biowest, Nuaill, France), $50 \mathrm{IU} / \mathrm{ml}$ penicillin, and $50 \mu \mathrm{g} / \mathrm{ml}$ streptomycin. SP2/0 cells, MethA fibrosarcoma cells and J774.1 cells were cultured in Roswell Park Memorial Institute (RPMI) 1640 (Invitrogen) supplemented with 10\% FBS, $50 \mathrm{IU} / \mathrm{ml}$ penicillin and $50 \mu \mathrm{g} / \mathrm{ml}$ streptomycin. The cells were grown at $37^{\circ} \mathrm{C}$ under $5 \% \mathrm{CO}_{2}$ in a humidified atmosphere and passaged before reaching confluency using $0.25 \%(\mathrm{w} / \mathrm{v})$ trypsin solution containing $0.04 \%(\mathrm{w} / \mathrm{v})$ EDTA.

Preparation of anti-PSK monoclonal antibodies. Anti-PSK monoclonal antibodies (mAbs) were prepared by immunizing BALB/c mice with PSK as follows. Two hundred micrograms of PSK was emulsified in an equal volume of Freund's complete adjuvant (Sigma-Aldrich Japan) and injected subcutaneously into female BALB/c mice (Charles River Laboratories Japan, Inc.). After 1 week, emulsion of PSK in Freund's incomplete adjuvant (Sigma-Aldrich Japan) was injected subcutaneously once a week for 6 weeks, followed by a mixture of PSK with TiterMax gold adjuvant (Interchim, Montluçon, France) once a week for 4 weeks. Seven days after the final booster, spleens were collected from the immunized mice. Freshly harvested spleen cells and myeloma cells (P2/0-Ag14 cells) were mixed at a ratio of $10: 1$, co-pelleted by centrifugation, and fused by adding PEG-1500 (Roche Applied Science, Indianapolis, IN, USA) solution to the pellet. The fused cells were centrifuged, resuspended in RPMI-1640 medium supplemented with 10\% FBS, $50 \mathrm{IU} / \mathrm{ml}$ penicillin, $50 \mu \mathrm{g} / \mathrm{ml}$ streptomycin and $1 \times 10^{-5} \mathrm{~mol} / 1$ hypoxanthine-aminopterin-thymidine (HAT, Sigma-Aldrich Japan) and plated in 96-well plates. After 1 week of HAT selection, the medium was changed to $1 \mathrm{X}$ hypoxanthine and thymidine (HT) medium. The hybridomas were allowed to grow for 10-15 days, and the supernatants from the hybridoma cultures were screened for anti-PSK mAb by an enzymelinked immunosorbent assay (ELISA). The hybridomas that produce high-titer antibody to PSK were monocloned by limited dilution. After repeated cloning, two hybridoma clones, $2 \mathrm{G} 9 \mathrm{mAb}$ and $5 \mathrm{G} 5 \mathrm{mAb}$, were selected for further characterization. The immunoglobulin subclass was determined with a mouse monoclonal antibody isotyping kit (IsoStrip; Roche Diagnostics, Indianapolis, IN). These two clones secreted immunoglobulins of subclasses $\operatorname{IgM}_{\mathrm{K}}$ and $\operatorname{IgM}_{\lambda}$, respectively. 2G9 mAb and 5G5 mAb were purified by HiTrap SP Sepharose FF (GE Healthcare UK Ltd., Buckinghamshire, UK) and HiLoad Superdex 200 columns (GE Healthcare) from hybridoma serum-free culture supernatants and used in subsequent experiments. Purified anti-PSK mAbs were biotinylated using a Sulfo-OSu biotinylation kit (Dojindo Laboratories, Kumamoto, Japan) according to the manufacturer's instructions.

Competitive ELISA using $2 G 9 \mathrm{mAb}$ and $5 G 5 \mathrm{mAb}$. A 96-well plate was coated with $50 \mu \mathrm{l}$ of PSK $(20 \mu \mathrm{g} / \mathrm{ml})$ per well and kept at $4{ }^{\circ} \mathrm{C}$ overnight. After adding $0,0.1,0.5$ or $1 \mu \mathrm{g} / \mathrm{ml}$ of 2G9 mAb (50 $\mu 1$ per well) as competitive antibody, $0.1 \mu \mathrm{g} / \mathrm{ml}$ of biotinylated $5 \mathrm{G} 5 \mathrm{mAb}$ ( $50 \mu 1$ per well) was added to the 96-well plate and incubated at room temperature (RT) for $2 \mathrm{~h}$. After washing each well with TBS containing $0.05 \%$ Tween-20 (TBS-T), $50 \mu 1$ of horseradish peroxidase (HRP)conjugated streptavidin (Zymed Laboratories, San Francisco, CA, USA; $0.1 \mu \mathrm{g} / \mathrm{ml}$ ) was added and incubated at RT for $1 \mathrm{~h}$. After washing, $100 \mu 1$ of glycine-citric acid buffer containing 2,2'-azino-di-(3-ethylbenzthiazoline sulfonate) and hydrogen peroxide (ABTS Substrate Solution, KPL Inc., KPL, Gaithersburg, MD, USA) was added to each well. Color development was stopped by the addition of $100 \mu 1$ of $5 \%$ sodium dodecyl sulfate solution (ABTS Peroxidase Stop Solution, KPL Inc.) and the optical density was measured at 405-630 nm.

Western blotting of PSK using anti-PSK mAb. PSK (1, 5, $10 \mu \mathrm{g}$ ) was dissolved in sodium Tris- $\mathrm{HCl}$ buffer (Daiichi Pure Chemicals Co., Ltd., Tokyo) containing sodium dodecyl sulfate (SDS), electrophoresed on 4-20\% polyacrylamide gels (Daiichi Pure Chemicals Co., Ltd.) after denaturing at $65^{\circ} \mathrm{C}$ for $15 \mathrm{~min}$, and transferred to Immobilon-P PVDF membrane (Millipore, Tokyo, Japan). The membrane was incubated in 10\% Block Ace (DS Pharma Biomedical Co., Ltd., Osaka, Japan) at RT for $1 \mathrm{~h}$. The membrane was then incubated with $0.5 \mu \mathrm{g} / \mathrm{ml}$ of anti-PSK $\mathrm{mAb}$ at RT for $2 \mathrm{~h}$, washed with TBS-T and incubated with $0.1 \mu \mathrm{g} / \mathrm{ml}$ of HRPconjugated goat anti-mouse IgM (Millipore) at RT for $1 \mathrm{~h}$. After washing, the membrane was visualized using TMB membrane peroxidase substrate (KPL Inc.). The silver staining was visualized using a silver staining kit (Daiichi Pure Chemicals Co., Ltd.).

Binding of anti-PSK $m A b$ to protein-degraded PSK. To investigate whether the anti-PSK mAbs (2G9 mAb and $5 \mathrm{G} 5 \mathrm{mAb}$ ) recognize the glucan or protein moiety of PSK, competitive ELISA was performed using PSK with degraded protein as competitor. The peptide moiety of PSK was decomposed by dissolving in anhydrous hydrazine and heating at 


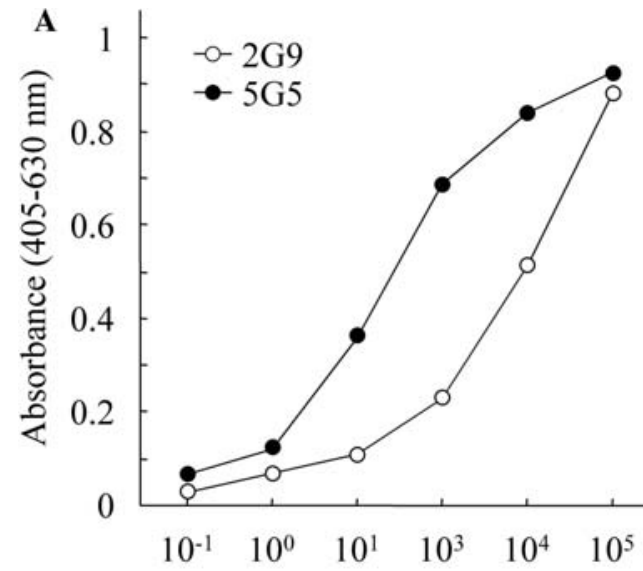

Antibody concentration $(\mathrm{ng} / \mathrm{ml})$

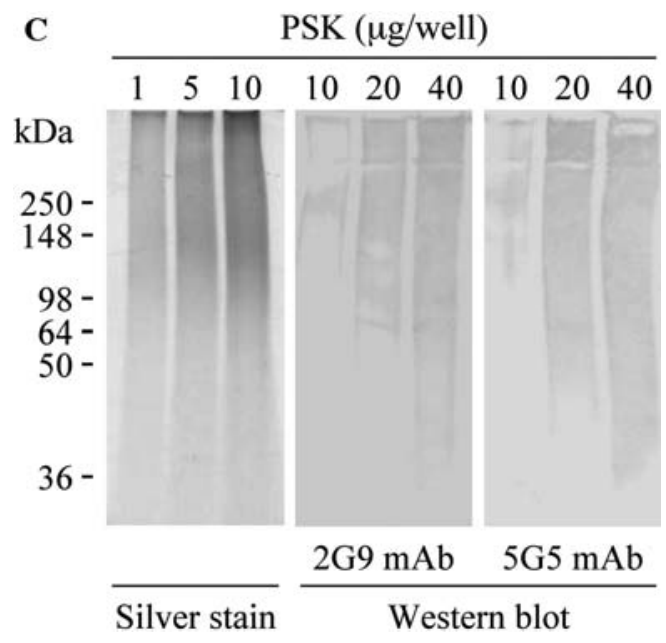

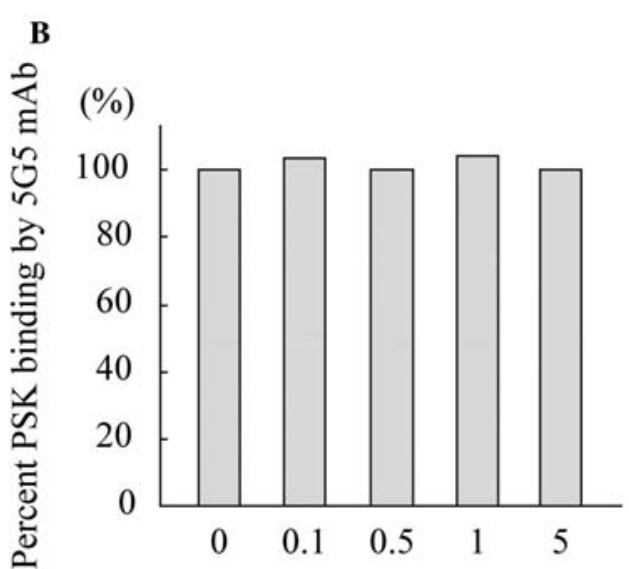

Competitor: $2 \mathrm{G} 9 \mathrm{mAb}(\mu \mathrm{g} / \mathrm{ml})$

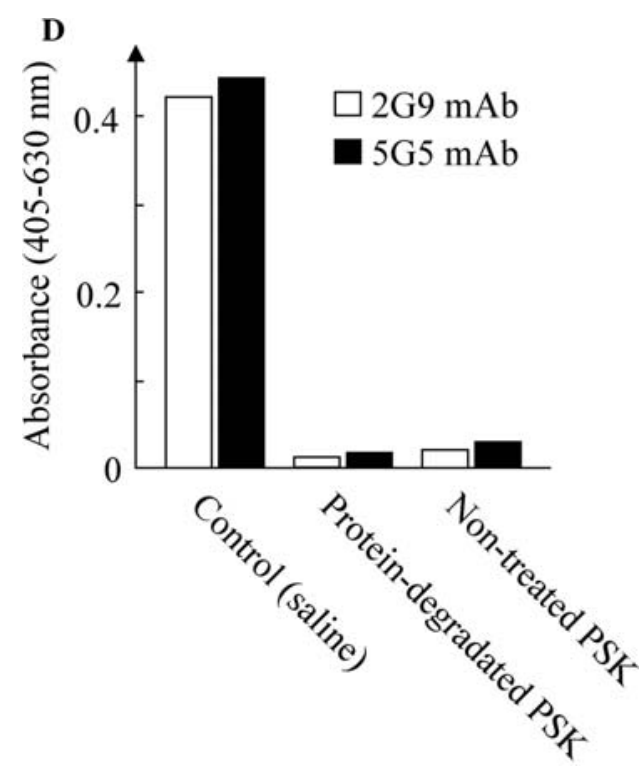

Figure 1. (A) Standard curve of anti-PSK monoclonal antibodies (mAb). Indirect ELISA was applied for estimation of the antibody binding capacity. Fifty microliters of $2 \mathrm{G} 9 \mathrm{mAb}$ and $5 \mathrm{G} 5 \mathrm{mAb}(0-4 \mu \mathrm{g} / \mathrm{ml})$ were dispensed into each PSK-coated well and incubated at RT for $2 \mathrm{~h}$. The titer of the antibody was determined by ELISA. The longitudinal axis and horizontal axis represent absorbance at $630 \mathrm{~nm}$ after subtraction of the background and dilution of the antibody, respectively. Each value represents the mean of three independent determinations. (B) Competitive ELISA to analyze the recognition site of antiPSK mAb. The $2 \mathrm{G} 9 \mathrm{mAb}(0,0.1,0.5$ or $1 \mu \mathrm{g} / \mathrm{ml})$ was used as competitor, and biotinyled-5G5 mAb $(0.1 \mu \mathrm{g} / \mathrm{ml})$ was used for detection. ELISA was performed as described in Materials and methods. Each column represents the mean of triplicate determinations. (C) Western blots of PSK using anti-PSK mAb. PSK (1, $5,10 \mu \mathrm{g}$ ) was subjected to SDS-PAGE and immunoblotted with anti-PSK mAbs (2G9 mAb or 5G5 mAb). These experiments were repeated at least thrice. Representative data are shown. (D) Competitive ELISA to evaluate binding of anti-PSK mAbs (2G9 mAb or 5G5 mAb) to hydrazine-treated (to decompose the protein moiety) and non-treated PSK. Each column represents the mean of triplicate determinations.

$100^{\circ} \mathrm{C}$ for $2 \mathrm{~h}$ in accordance with identification scheme (15). Competitive ELISA was performed according to the above procedures.

Competitive ELISA for PSK and other glucans using the anti$P S K m A b s$. Competitive ELISA was performed to examine whether the anti-PSK mAbs (2G9 mAb and 5G5 mAb) recognize glucans having similar structures as PSK. AntiPSK mAb $(1 \mu \mathrm{g} / \mathrm{ml})$ and $10 \mu \mathrm{g} / \mathrm{ml}$ of glucan (PSK, cellulose, laminarin, glycogen or dextran) were mixed and incubated at RT for $1 \mathrm{~h}$. These mixtures were evaluated by competitive ELISA as described above.

Neutralization of PSK's cytostatic activity by anti-PSK mAbs. To examine whether the anti-PSK mAbs (2G9 mAb and
$5 \mathrm{G} 5 \mathrm{mAb}$ ) neutralize the cytostatic activity of PSK, proliferation of MethA fibrosarcoma cells was evaluated by MTT [3-(4,5-dimethylthiazol-2-yl)-2, 5-diphenyltetrazolium bromide] assay. MethA fibrosarcoma cells were plated in a 96-well culture dish at a density of $1 \times 10^{3}$ cells $/ 100 \mu 1 /$ well, and cultured in a $5 \% \mathrm{CO}_{2}$ incubator at $37^{\circ} \mathrm{C}$ for $24 \mathrm{~h}$. AntiPSK mAb and PSK were mixed in various ratios in $50 \mathrm{mmol} / \mathrm{l}$ Tris- $\mathrm{HCl}$ buffer ( $\mathrm{pH} 7.5$ ) containing $0.2 \%$ bovine serum albumin and $0.2 \mathrm{~mol} / \mathrm{l}$ sodium chloride and incubated for $1 \mathrm{~h}$ at $37^{\circ} \mathrm{C}$. The mixture was added to MethA fibrosarcoma cells in cultured dish, and cultured for another $72 \mathrm{~h}$. Three $\mathrm{h}$ before the end of culturing, 1/10 volume of MTT $(5 \mathrm{mg} / \mathrm{ml}$ in PBS) was added to each well. After incubation at $37^{\circ} \mathrm{C}$ for $3 \mathrm{~h}$, the supernatant was removed, and dimethylsulfoxide (DMSO; $100 \mu \mathrm{l} /$ well) was added. The absorbance of formazan was 
measured at $570 \mathrm{~nm}$ with reference at $630 \mathrm{~nm}$ using a Bio-Rad Microplate Reader 550 (Bio-Rad Laboratories Inc., Tokyo, Japan). Changes in cell number were expressed as mean \pm SD percent cell proliferation compared with control cells.

Neutralization of PSK binding to transforming growth factor- $\beta 1$ by anti-PSK $m A$ bs. The binding of PSK to mouse transforming growth factor- $\beta 1$ (TGF- $\beta_{1}$ ) (R\&D Systems Europe Ltd., Abingdon, UK) was evaluated according to the modified method of Hoshi et al (16). Briefly, anti-PSK monoclonal antibody and PSK were mixed and incubated for $1 \mathrm{~h}$ at $37^{\circ} \mathrm{C}$. Recombinant mouse TGF- $\beta_{1}$ was added to the anti-PSK mAb-PSK mixture and incubated for another $2 \mathrm{~h}$ at $37^{\circ} \mathrm{C}$. The TGF- $\beta_{1}$-sensitive Mv1Lu cells were plated in a 96-well culture dish at a density of $1 \times 10^{4}$ cells/100 $\mu \mathrm{l} /$ well and cultured in a $5 \% \mathrm{CO}_{2}$ incubator at $37^{\circ} \mathrm{C}$ for $24 \mathrm{~h}$. The reaction mixture was added to the cells and incubated for another $24 \mathrm{~h}$. Cell numbers were determined by MTT assay, and the changes were expressed as the mean \pm SD percent cell proliferation compared with control cells.

Antitumor effect of PSK in NOD/scid mice. Exponentially growing MethA fibrosarcoma cells were dispersed with $0.25 \%$ $(\mathrm{w} / \mathrm{v})$ trypsin solution containing $0.04 \%(\mathrm{w} / \mathrm{v})$ EDTA and resuspended in PBS at a density of $1 \times 10^{7} / \mathrm{ml}$. MethA fibrosarcoma cells $\left(1 \times 10^{6} /\right.$ mice $)$ were implanted subcutaneously. into the flanks of severely-immunodeficient NOD.CB17Prkdc scid/J (NOD/scid) mice. PSK and anti-PSK mAb were dissolved in saline and administered intravenously at given doses three times a week for 17 days. The body weight and tumor volume of each mouse were measured at least once a week. To determine tumor volume, two bisecting diameters of a tumor were measured using a slide caliper, and the tumor volume was calculated using the following formula: tumor volume $=$ length $\mathrm{x}(\text { width })^{2} \times 0.5236(17)$. At the end of the experiment, the tumor, spleen and liver was removed and weighed, and fixed in 10\% formaldehyde neutral buffer solution. As a rule, each experimental group consisted of six mice, and the same experiment was repeated at least twice. Tumor growth curves were plotted as the mean volume \pm standard error (SE).

Immunohistochemistry. Tumor tissues, liver and spleen were fixed in $10 \%$ formaldehyde neutral buffer solution and embedded in paraffin. Paraffin sections $(4-\mu \mathrm{m})$ were deparaffinized with xylene and ethanol, treated with $3 \%$ hydrogen peroxide solution for $20 \mathrm{~min}$ to inactivate endogenous peroxidase and blocked with $2 \%$ porcine plasma in TBS for $15 \mathrm{~min}$ to reduce non-specific binding. Then biotinylated $2 \mathrm{G} 9 \mathrm{mAb}$ was added, and the sections were incubated at RT for $2 \mathrm{~h}$. After washing three times with TBS, horseradish peroxidase-labeled streptavidin was added and incubated at room temperature for $1 \mathrm{~h}$, followed by three washes with TBS. Immunoreaction was visualized using Liquid DAB Chromogen (Dako Japan Co. Ltd., Kyoto, Japan). The sections were counterstained with hematoxylin, mounted on glass slides with Entellan Neu (Merck) and examined under a microscope. At the same time, hematoxylin and eosin (H\&E) staining was performed on serial sections for morphological evaluation.

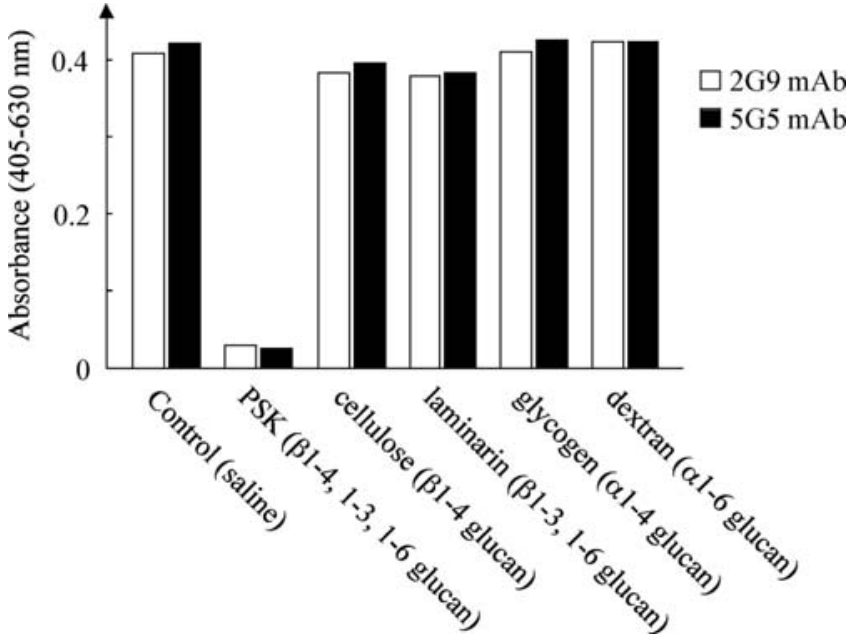

Figure 2. Binding of anti-PSK mAb to other glucans. To examine whether the anti-PSK mAbs (2G9 mAb or $5 \mathrm{G} 5 \mathrm{mAb}$ ) recognizes glucans with similar structures as PSK, competitive ELISA was performed as described in Materials and methods. PSK, cellulose, laminarin, glycogen or dextran was used as competitor for anti-PSK mAb. Each column represents the mean of triplicate determinations.

Statistical analysis. All data are expressed as the means \pm SD or SE. Statistical significance was determined by Student's ttest. P-values $<0.05$ were considered significant.

\section{Results}

Recognition site of anti-PSK mAbs. The standard curve of anti-PSK monoclonal antibodies (mAb) is shown in Fig. 1A. PSK is a complex of polysaccharide and protein, therefore competitive ELISA was performed to examine the recognition sites of the two anti-PSK mAb; $2 \mathrm{G} 9 \mathrm{mAb}$ or $5 \mathrm{G} 5 \mathrm{mAb}$, in the glucan or polysaccharide moiety of PSK. First, we investigated whether $2 \mathrm{G} 9 \mathrm{mAb}$ and $5 \mathrm{G} 5 \mathrm{mAb}$ recognize the same epitope. After adding $2 \mathrm{G} 9 \mathrm{mAb}$ as a competitive antibody to PSK-coated 96-well plate, biotinyled-5G5 mAb was used to detect PSK in the plate. As shown in Fig. 1B, binding of $2 \mathrm{G} 9 \mathrm{mAb}$ was unaffected by competition with $5 \mathrm{G} 5 \mathrm{mAb}$. The same result was obtained when $2 \mathrm{G} 9 \mathrm{mAb}$ was used as the competitive antibody and 5G5 as the detecting antibody (data not shown). These results show that 2G9 mAb and 5G5 $\mathrm{mAb}$ recognize different sites on PSK. Although the average molecular weight of PSK is $\sim 100,000$, it is consisted of a mixture of molecules with a broad molecular weight range, and the degree of polymerization ranges from a few thousands to hundreds of thousands. Western blotting was performed to investigate the molecular weight range of PSK with which the anti-PSK mAbs react. Since the staining patterns of the Western blots were similar to that of silver staining, the Western blots demonstrated that both mAbs recognize PSK for a broad molecular weight range (Fig. 1C). Next, we investigated whether the anti-PSK mAbs recognize the polysaccharide chain or the peptide of PSK. When the reactivity of the mAbs against PSK with proteins degraded by hydrazine was evaluated by ELISA, both mAbs bound the protein-depleted PSK similar to non-treated PSK (Fig. 1D). Therefore, the epitopes recognized by $2 \mathrm{G} 9 \mathrm{mAb}$ and $5 \mathrm{G} 5 \mathrm{mAb}$ are located in the polysaccharide moiety of PSK. 
A

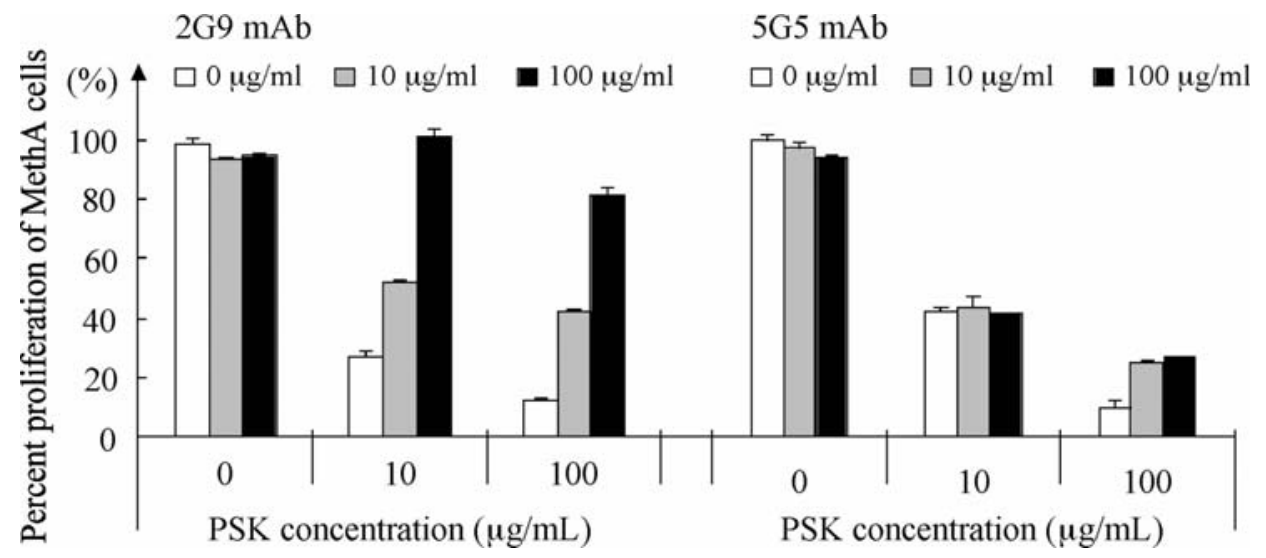

B

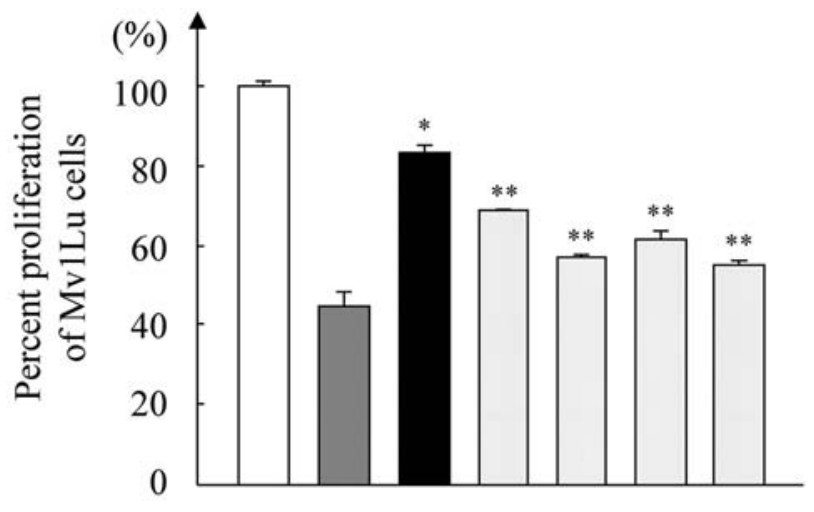

$\begin{array}{llllllll}\text { TGF- } \beta 1(1 \mathrm{ng} / \mathrm{ml}) & - & + & + & + & + & + & + \\ \operatorname{PSK}(50 \mu \mathrm{g} / \mathrm{ml}) & - & - & + & + & + & + & + \\ 2 \mathrm{G} 9 \mathrm{mAb}(50 \mu \mathrm{g} / \mathrm{ml}) & - & - & - & + & - & - & - \\ 2 \mathrm{G} 9 \mathrm{mAb}(100 \mu \mathrm{g} / \mathrm{ml}) & - & - & - & - & + & - & - \\ 5 \mathrm{G} 5 \mathrm{mAb}(50 \mu \mathrm{g} / \mathrm{ml}) & - & - & - & - & - & + & - \\ 5 \mathrm{G} 5 \mathrm{mAb}(100 \mu \mathrm{g} / \mathrm{ml}) & - & - & - & - & - & - & +\end{array}$

Figure 3. (A) Effect of anti-PSK mAb on cytostatic activity of PSK. MethA fibrosarcoma cells were plated in 96-well culture dish at a density of $1 \times 10^{3}$ cells/ $100 \mu \mathrm{l} /$ well, and cultured for $24 \mathrm{~h}$. Anti-PSK mAb and PSK were mixed at the indicated ratios, in $50 \mathrm{mmol} / 1 \mathrm{Tris}-\mathrm{HCl}$ buffer (pH 7.5) containing $0.2 \%$ bovine serum albumin and $0.2 \mathrm{~mol} / 1$ sodium chloride (binding buffer) and incubated for $1 \mathrm{~h}$ at $37^{\circ} \mathrm{C}$. The mixture was added to MethA fibrosarcoma cells and cultured for another $72 \mathrm{~h}$. Viable cell number was determined by MTT assay, and expressed as percent cell proliferation compared with control cells without addition of PSK or mAb. Data are expressed as mean \pm SD ( $n=3)$. (B) Effect of anti-PSK mAb on TGF- $\beta_{1}$-binding activity of PSK. PSK and 2 G9 mAb or $5 \mathrm{G} 5 \mathrm{mAb}$ were mixed in binding buffer at the indicated ratios and incubated for $1 \mathrm{~h}$ at $37^{\circ} \mathrm{C}$. Recombinant mouse TGF- $\beta_{1}$ was added to the mixtures and incubated for another $2 \mathrm{~h}$ at $37^{\circ} \mathrm{C}$. The mixtures were added to TGF- $\beta_{1}$-sensitive Mv1Lu mink lung epithelial cells, and incubated for $24 \mathrm{~h}$. Viable cell number was determined by MTT assay, and expressed as percent cell proliferation compared with control cells. Data are expressed as the mean \pm SD ( $\mathrm{n}=3$ ). ${ }^{*} \mathrm{p}<0.001$ ( $\mathrm{vs}$. grey column), ${ }^{* *} \mathrm{p}<0.01$ (vs. black column).

Specificity of anti-PSK mAbs. To confirm that $2 \mathrm{G} 9 \mathrm{mAb}$ and $5 \mathrm{G} 5 \mathrm{mAb}$ specifically recognize the polysaccharide moiety of PSK, we investigated whether the mAbs also react with other B-glucan structures. In a competitive ELISA assay using $10 \mu \mathrm{g} / \mathrm{ml}$ each of PSK [B-(1,4)(1,3)(1,6)-D-glucan], cellulose [ß-(1,4)-D-glucan], laminarin [B-(1,3)(1,6)-D-glucan], glycogen [ß-(1,4)-D-glucan] and dextran [ $\beta-(1,6)-D$-glucan], only PSK competed for binding to $2 \mathrm{G} 9 \mathrm{mAb}$ but not the other glucan structures (Fig. 2). The same results were obtained with $5 \mathrm{G} 5 \mathrm{mAb}$. Since both mAbs recognize the PSK structure specifically and do not cross-react with other glucans, they are both highly specific for PSK.

Effect of anti-PSK mAbs on PSK-induced cytostatic effect. As a direct anti-cancer action, PSK is known to inhibit the growth of cancer cells (cytostatic effect). We investigated whether the anti-PSK mAbs neutralize the cytostatic effect of PSK. MethA cells known to be sensitive to PSK were used, and cell proliferation was examined in the co-presence of PSK and anti-PSK mAb. In the absence of $2 \mathrm{G} 9 \mathrm{mAb}$, PSK dosedependently inhibited MethA cell proliferation by $40 \%$ at a concentration of $10 \mu \mathrm{g} / \mathrm{ml}$ and $90 \%$ at $100 \mu \mathrm{g} / \mathrm{ml}$. The addition of $10 \mu \mathrm{g} / \mathrm{ml}$ and $100 \mu \mathrm{g} / \mathrm{ml}$ of $2 \mathrm{G} 9 \mathrm{mAb}$ dose-dependently restored MethA cell proliferation. On the other hand, the addition of 5G5 mAb did not restore MethA cell proliferation (Fig. 3A). Since $2 \mathrm{G} 9 \mathrm{mAb}$ is capable of completely neutralizing the cytostatic effect of PSK, its epitope probably coincides with the active structure responsible for the cytostatic effect of PSK.

Effect of anti-PSK $m A$ b on PSK-TGF- $\beta_{1}$ binding. TGF- $\beta_{1}$ is a cytokine known to inhibit the growth and proliferation of 

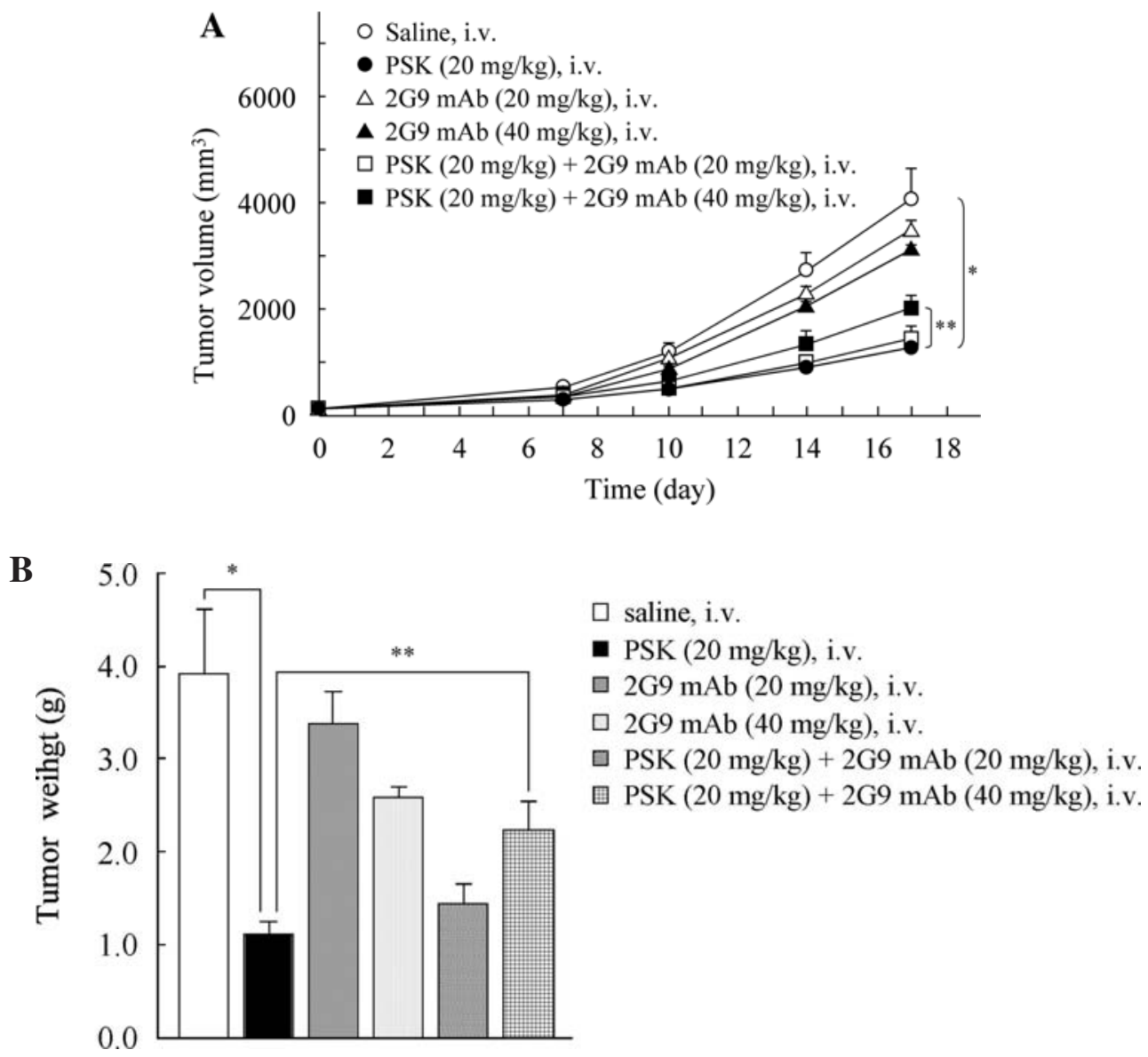

Figure 4. Effect of $2 \mathrm{G} 9 \mathrm{mAb}$ on in vivo antitumor activity of PSK. MethA fibroblast cells $\left(1 \times 10^{6} / \mathrm{mice}\right)$ were implanted subcutaneously into the flanks of severely immunodeficient NOD.CB17-Prkdcscid/J (NOD/scid) mice. PSK, 2G9 mAb or a mixture of the two were dissolved in saline and administered intravenously at thrice a week (A). Data are expressed as the mean $\pm \mathrm{SE}(\mathrm{n}=6)$. The experiments were repeated three times. Representative data are shown. (A) Changes in tumor volume over time. ${ }^{*} \mathrm{p}=0.001$ ( $\mathrm{v}$ vs. $\bullet$ ) and ${ }^{* *} \mathrm{p}=0.048\left(\bullet\right.$ vs. $\bullet$ ). (B) Tumor weights on day 17 of implantation. ${ }^{*} \mathrm{p}=0.002$ and ${ }^{* * *} \mathrm{p}=0.013$.

immunocompetent cells, and its overproduction causes immunosuppression. A previous study confirmed that PSK binds TGF- $\beta_{1}$ directly and inhibits its biological activity (6). Therefore, we examined whether the anti-PSK mAbs bind PSK and block the interaction between PSK and TGF- $\beta_{1}$. Representative findings are shown in Fig. 3B. The addition of the PSK-TGF- $\beta_{1}$ complex to an in vitro culture of Mv1Lu cells, a cell line sensitive to TGF- $\beta_{1}$, promoted cell proliferation compared to the addition of TGF- $\beta_{1}$ alone $(p<0.001)$ suggesting that the PSK-TGF- $\beta_{1}$ complex has a lower growth suppression activity than TGF- $\beta_{1}$. When $2 \mathrm{G} 9 \mathrm{mAb}$ was added to PSK and TGF- $\beta_{1}$, the in vitro proliferation of Mv1Lu cells was reduced compared to the addition of PSK-TGF- $\beta_{1}$ complex $(\mathrm{p}<0.01)$. These results suggest that $2 \mathrm{G} 9 \mathrm{mAb}$ competes for the TGF$\beta_{1}$-binding site of PSK and prevents the formation of PSKTGF- $\beta_{1}$ complex. The same results were obtained for $5 \mathrm{G} 5 \mathrm{mAb}$ $(\mathrm{p}<0.01)$. Thus, it is possible that $2 \mathrm{G} 9 \mathrm{mAb}$ and $5 \mathrm{G} 5 \mathrm{mAb}$ inhibits the TGF- $\beta_{1}$-blocking activity of PSK, and the mAb epitope may at least partially overlap with the TGF- $\beta_{1}$-binding site of PSK.

Effect of anti-PSK mAbs on PSK-induced TNF- $\alpha$ production. Next, we investigated whether $2 \mathrm{G} 9 \mathrm{mAb}$ and $5 \mathrm{G} 5 \mathrm{mAb}$ inhibit PSK-induced cytokine production by immune cells. A mixture of PSK and anti-PSK mAb was added to cultured monocytic J774.1 cells (a cell line that produces TNF- $\alpha$ by PSK), and TNF- $\alpha$ secreted in the supernatant was measured by ELISA. Both $2 \mathrm{G} 9 \mathrm{mAb}$ and $5 \mathrm{G} 5 \mathrm{mAb}$ did not inhibit PSK-induced TNF- $\alpha$ production (data not shown).

Antitumor effect of PSK evaluated in NOD/scid mice. The in vitro results obtained so far demonstrated that PSK exhibits direct action against tumor cells. Next we examined whether PSK also exhibits antitumor effect in vivo via direct actions. Using a tumor model of subcutaneous implantation of MethA tumor in severely immunodeficient NOD/scid mice (treated by asialo GM1 antibody), we investigated the therapeutic efficacy of PSK and the effect of $2 \mathrm{G} 9 \mathrm{mAb}$. The mean tumor volume on day 17 after MethA implantation was $4566 \mathrm{~mm}^{3}$ in control mice compared with $1305 \mathrm{~mm}^{3}$ in PSK-treated mice, showing significant suppression of tumor growth in PSK-treated mice $(\mathrm{p}=0.001)$ (Fig. 4A). Since severely immunodeficient NOD/ scid mice were used in this study, the antitumor effect can be considered to be a direct action of PSK. Furthermore, the mean tumor weight was $3.92 \mathrm{~g}$ in control mice and $1.09 \mathrm{~g}$ in PSK-treated mice, also showing significant suppression of tumor growth in PSK-treated mice $(\mathrm{p}=0.002)$ (Fig. 4B). 
Saline-administered group
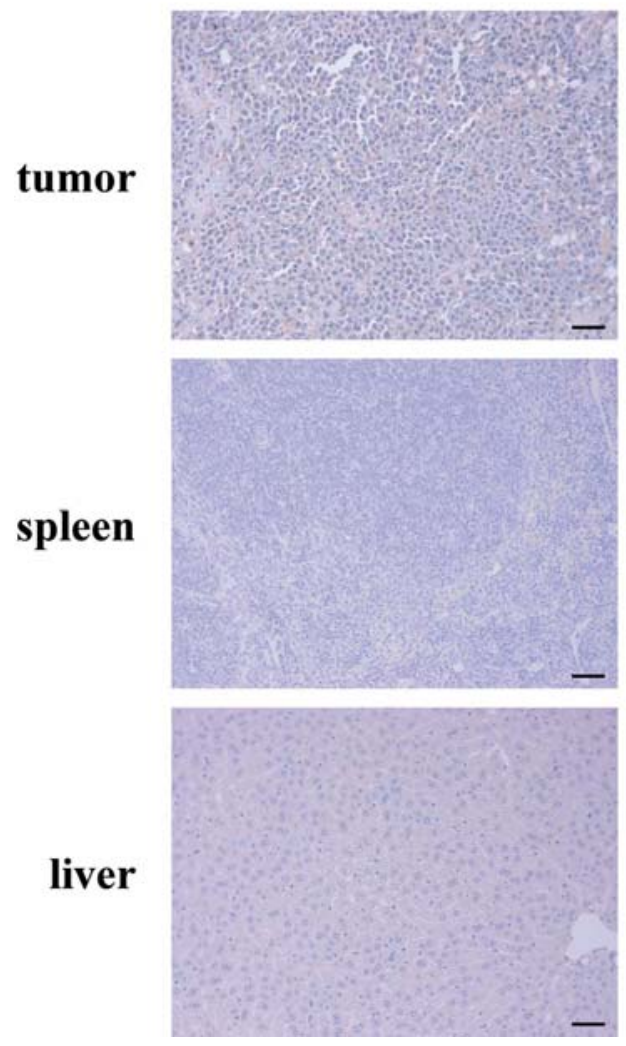

PSK-administered group
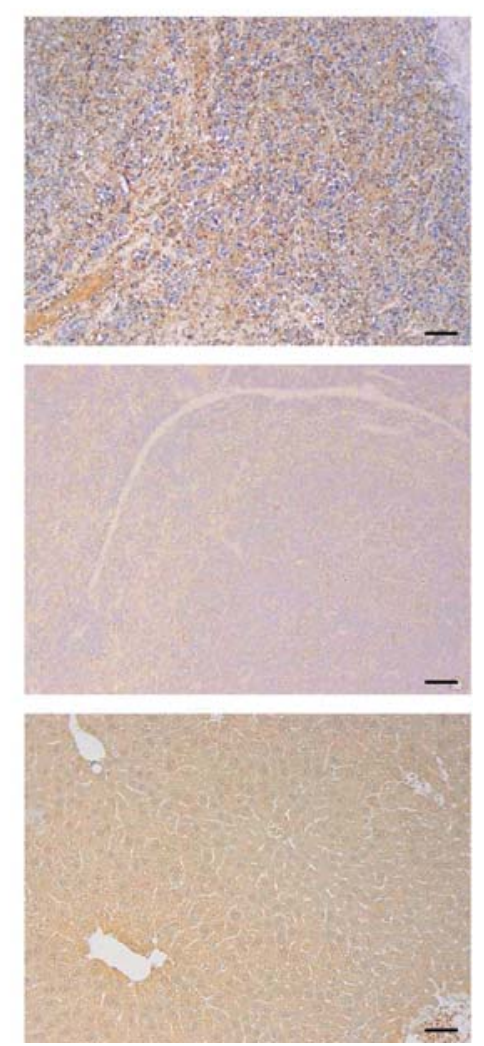

Figure 5. Immunostaining of active structure of PSK in various tissues. The tumor, spleen and liver were removed on day 17 after MethA tumor implantation. These samples were fixed with formalin, and paraffin sections were prepared, which were then stained with 2G9 mAb. Top, MethA fibroblast tumor. Middle, spleen. Bottom, liver. Bar, $50 \mu \mathrm{m}$. All experiments were repeated at least twice and representative micrographs are shown.

Effect of $2 G 9 \mathrm{mAb}$ on in vivo antitumor effect of PSK. We investigated whether the neutralizing antibody $2 \mathrm{G} 9 \mathrm{mAb}$ neutralizes the effect of PSK in vivo. The mean tumor volume was $2137 \mathrm{~mm}^{3}$ in mice administered PSK $(20 \mathrm{mg} / \mathrm{kg}$ ) and $2 \mathrm{G} 9 \mathrm{mAb}(40 \mathrm{mg} / \mathrm{kg})$, showing a significant reversal in tumor proliferation compared with $1305 \mathrm{~mm}^{3}$ in mice administered PSK alone ( $\mathrm{p}=0.048)$ (Fig. 4A). In addition, when comparing tumor weight, the mean weight was $2.23 \mathrm{~g}$ in the group treated with PSK $(20 \mathrm{mg} / \mathrm{kg})$ and $2 \mathrm{G} 9 \mathrm{mAb}(40 \mathrm{mg} / \mathrm{kg})$ and $1.09 \mathrm{~g}$ in the group treated with PSK alone ( $\mathrm{p}=0.013)$ (Fig. 4B). These results indicate that $2 \mathrm{G} 9 \mathrm{mAb}$ suppresses the antitumor effect of PSK in vivo.

Tumor and tissue distribution of the active structure after intravenously administration of PSK. To determine whether PSK is absorbed into blood and reaches tumor cells and immune cells while maintaining its bioactive structure, we performed immunohistochemical studies using anti-PSK mAbs. NOD/scid mice implanted subcutaneously with MethA were given intravenous injection of PSK at a dose of $20 \mathrm{mg} / \mathrm{kg}$ on thrice a week, and were sacrificed on day 17. Histological specimens were prepared by the standard procedures and stained immunohistochemically using the $2 \mathrm{G} 9 \mathrm{mAb}$, which is an antibody that neutralizes the direct actions of PSK. PSK was detected in the MethA tumor cells, spleen cells and liver cells (Fig. 5). These results suggest that PSK might come in contact with tumor cells and immune cells, while preserving the bioactive structure.

\section{Discussion}

Glucans are a structurally diverse group of polysaccharides containing D-glucopyranosyl units. They are involved in various physiological functions and have a wide variety of sources such as barley, oats, algae, bacteria, yeasts, fungi and mushrooms. Unlike low molecular weight substances, polysaccharides cannot be detected and quantitated by high performance liquid chromatography and mass spectral analysis. Therefore, the Limulus test and ELISA using specific antibody are the common detection methods. The Limulus test is generally used to detect LPS and B1-3 glucan, but this test reacts with all the substances containing B-D-glucan and is therefore not highly specific. A monoclonal antibody against proteoglycan (ß1-3 glucan, B1-6 glucan) derived from Grifola frondosa cross-reacts with other compounds containing B1-3 and B1-6 branches, such as schizophyllan, lentinan, scleroglucan, pustulan, curdlan and laminarin, and is not a proteoglycan-specific antibody (18). Endoh et al (14) used rabbit anti-PSK polyclonal antibodies to examine the intratumoral distribution of PSK. Due to the relatively low specificity of polyclonal antibodies, efforts have been made to raise mouse monoclonal antibodies against PSK. However, since PSK is a protein-bound polysaccharide, the attempts so far have not produced monoclonal antibodies with high potency (unpublished data).

The objectives of the present study were to produce mouse monoclonal antibodies that are highly specific and recognize 
the active structure of PSK, and to use this antibody to examine the intratumoral accumulation of PSK. In this study, we immunized Balb/c mice with a larger amount of antigen $(200 \mu \mathrm{g})$ than is normally used for immunization, for a period of 12 weeks. By screening using neutralization of PSK activity as indicator, two clones were obtained: $2 \mathrm{G} 9 \mathrm{mAb}\left(\mathrm{IgM}_{\kappa}\right)$ and $5 \mathrm{G} 5 \mathrm{mAb}\left(\operatorname{IgM}_{\lambda}\right)$. Both $\mathrm{mAbs}$ recognize PSK molecules over a wide molecular weight range (Figs. 1 and 2) and do not crossreact with other glucan standard substances. A noteworthy finding is that although PSK contains $\beta 1-4, \beta 1-6$ and B1-3 glucan structures, the 2G9 mAb and 5G5 mAb obtained in the present study do not react with a $\$ 1-4$ glucan (cellulose), a $\beta 1-3, \beta 1-6$ glucan (laminarin), an $\alpha 1-4$ glucan (glycogen) or an $\alpha 1-6$ glucan (dextran). One explanation is that PSK is not a homogeneous glucan structure but possesses complex and intricate branch structures and the mAbs recognize this specific structure of PSK.

The $2 \mathrm{G} 9 \mathrm{mAb}$ and $5 \mathrm{G} 5 \mathrm{mAb}$ obtained from this study recognize different epitopes in the PSK molecule (Fig. 1D). Using these two mAbs, we examined their effect on the cytostatic effect of PSK. While 2G9 mAb completely abrogated the cytostatic effect, which is one of the direct actions of PSK, 5G5 mAb had almost no neutralizing effect on the cytostatic activity of PSK (Fig. 3A). These results suggest that the $2 \mathrm{G} 9 \mathrm{mAb}$ epitope is a structure associated with the cytostatic activity of PSK. Next, we investigated the TGF- $\beta_{1}$ blocking effect of PSK. In this experiment, addition of $2 \mathrm{G} 9$ $\mathrm{mAb}$ or $5 \mathrm{G} 5 \mathrm{mAb}$ even in an excess amount did not completely inhibit the TGF- $\beta_{1}$-blocking effect of PSK (Fig. 3B). A possible reason is that multiple TGF- $\beta_{1}$-blocking sites are present in the PSK molecule and the mAb only recognizes one of them. To investigate the effect of PSK on immune cells, we examined the effect of the mAbs on PSK-induced TNF- $\alpha$ production. Both mAbs had absolutely no effect on this activity (data not shown). Production of antibodies that neutralize the cytokineinducing activity of PSK should be attempted in the future.

Ikuzawa et al (19) produced ${ }^{14} \mathrm{C}$-labeled PSK and studied the pharmacodynamics of PSK in SD rats. They detected ${ }^{14} \mathrm{C}$-labeled low molecular weight substances in the blood at $1 \mathrm{~h}$ after oral administration, followed by the appearance of ${ }^{14} \mathrm{C}$-labeled high molecular weight substances with time, and almost complete disappearance of labeled substance in the blood $72 \mathrm{~h}$ later. However, only ${ }^{14} \mathrm{C}$ was monitored in that experiment, and it remains unknown whether the absorbed substance was the bioactive structure of PSK. In the present study, we investigated whether PSK is distributed in tumor and immune tissues by immunohistochemistry using 2G9 mAb, which is an anti-PSK neutralizing antibody. Immunodeficient NOD/scid mice were implanted subcutaneously with MethA tumor, and PSK was administered by the intravenous route. On day 17 after MethA tumor implantation, tumor growth was significantly inhibited in the PSK-treated mice compared to control mice (Fig. 4). When the same experiment was conducted using Balb/c mice, tumor growth was almost absent and the tumor even disappeared in some mice (data not shown). However, using NOD/scid mice in the present study, PSK treatment reduced tumor growth to only $29 \%$ by volume compared with that in control mice on day 17 after tumor implantation (Fig. 4A). In this model animal almost completely deficient in immunological function, the residual tumor growth not inhibited by PSK treatment is speculated to reflect the antitumor effect of PSK mediated by the immune system. To investigate the distribution of PSK in the body, tumor tissues and organs were obtained on day 17 after MethA implantation and examined by immunohistochemistry using 2G9 mAb. This experiment confirmed that PSK not only reaches the tumor tissue but also the spleen and liver (Fig. 5). Since 2G9 $\mathrm{mAb}$ used in this study is a neutralizing antibody, these results suggest that PSK with its bioactive structure intact reaches the tumor and directly attacks the tumor cells. However, the direct action to the cell of PSK is cytostatic, but not cytotoxic because PSK inhibits cell proliferation, but does not decrease in number of cells. So, it is suggested that PSK is not affecting any normal tissues other than tumor tissue (data not shown).

Considering the future application of the monoclonal antibody to patients, we have planned to develop an assay system for the detection and quantitation of PSK in blood using ELISA. When monitoring of blood PSK concentration becomes available, it may be possible to differentiate patients who are good or bad absorbers of PSK to predict the response to PSK therapy. Furthermore, individualized dose adjustment while measuring blood PSK concentrations may also be realized.

The anti-PSK monoclonal antibody; 2G9 mAb, produced in the present study is a PSK-specific antibody that does not cross-react with various glucans with structures similar to PSK. Furthermore, $2 \mathrm{G} 9 \mathrm{mAb}$ is capable of neutralizing the actions of PSK in inhibiting tumor cell growth and blocking TGF- $\beta_{1}$, a strong immunosuppressive substance. This antibody that neutralizes the activity of PSK is expected to be a useful tool in the elucidation of the bioactive structure of PSK. Many attempts have been made to identify the active sites of PSK, but so far the active structure has not been elucidated. One of the reasons is that PSK is not a homogeneous structure but is consisted of diverse molecular structures. Consequently, cleavage, digestion and column chromatographic fractionation are difficult to perform, and evaluation of the activity of the fractions depends on assaying the biological activity. Because $2 \mathrm{G} 9 \mathrm{mAb}$ is a neutralizing antibody, the epitope is likely to coincide with or in close vicinity of the active structure of the molecule. Through further analysis of the epitope, it is possible that identification of the active structure and elucidation of the exact mechanism of action of PSK may be realized.

Finally, the use of this anti-PSK monoclonal antibody in the clinical setting may provide a simple and precise method of measuring blood concentrations of the active structure after PSK oral administration. Consequently, selection of patients who are good absorbers of PSK (PSK responders) and individualized dosage adjustment may be anticipated.

\section{Acknowledgements}

This study was conducted at Kureha Corp., Tokyo, Japan and Osaka City University, Osaka, Japan.

\section{References}

1. Ebina $\mathrm{T}$ and Kohya $\mathrm{H}$ : Antitumor effector mechanism at a distant site in the double grafted tumor system of PSK, a proteinbound polysaccharide preparation. Cancer Sci 79: 957-964, 1988. 
2. Harada M, Matsunaga K, Oguchi Y, et al: The involvement of transforming growth factor beta in the impaired antitumor T-cell response at the gut-associated lymphoid tissue (GALT). Cancer Res 55: 6146-6151, 1995.

3. Harada M, Matsunaga K, Oguchi Y, et al: Oral administration of PSK can improve the impaired anti-tumor $\mathrm{CD}^{+} \mathrm{T}$-cell response in gut-associated lymphoid tissue (GALT) of specific-pathogenfree mice. Int J Cancer 70: 362-372, 1997.

4. Hirose K, Zachariae CO, Oppenheim JJ and Matsushima K: Induction of gene expression and production of immunomodulating cytokines by PSK in human peripheral blood mononuclear cells. Lymphokine Res 9: 475-483, 1990.

5. Kariya Y, Okamoto N, Fujimoto T, et al: Lysis of fresh human tumor cells by autologous peripheral blood lymphocytes and tumor-infiltrating lymphocytes activated by PSK. Cancer Sci 82: 1044-1050, 1991.

6. Matsunaga K, Hosokawa A, Oohara M, Sugita N, Harada M and Nomoto K: Direct action of a protein-bound polysaccharide, PSK, on transforming growth factor- $\beta$. Immunopharmacology 40: 219-230, 1998.

7. Pedrinaci S, Algarra I and Garrido F: Protein-bound polysaccharide (PSK) induces cytotoxic activity in the NKL human natural killer cell line. Int J Clin Lab Res 29: 135-140, 1999.

8. Sugiyama Y, Saji S, Kato M, Yasuda K and Adachi T: Basic and clinical studies on antitumor mechanism of PSK. J Immunother 20: 412, 1997.

9. Wada T, Wakamatsu Y, Bannai K, et al: Suppression mechanism of angiogenesis PSK. Ann Cancer Res Ther 10: 93-106, 2002.

10. Yefenof E: Apoptosis in the immune system and cancer: common denominators and bilateral implications. Biotherapy 12: 1-5, 1998.

11. Yefenof E, Gafanovitch I, Oron E, Bar M and Klein E: Prophylactic intervention in radiation-leukemia-virus-induced murine lymphoma by the biological response modifier polysaccharide K. Cancer Immunol Immunother 41: 389-396, 1995.
12. Zhang $\mathrm{H}$, Morisaki $\mathrm{T}$, Matsunaga $\mathrm{H}$, et al: Protein-bound polysaccharide PSK inhibits tumor invasiveness by downregulation of TGF-betal and MMPs. Clin Exp Metastasis 18: 343-352, 2000

13. Zhang H, Morisaki T, Nakahara C, et al: PSK-mediated NFkappaB inhibition augments docetaxel-induced apoptosis in human pancreatic cancer cells NOR-P1. Oncogene 22: 2088-2096, 2003.

14. Endoh H, Matsunaga K, Yoshikumi C, Kawai Y, Suzuki T and Nomoto K: Production of antiserum against antitumor proteinbound polysaccharide preparation, PSK (Krestin) and its pharmacological application. Int J Immunopharmacol 10: 103-109, 1988 .

15. Yosizawa Z, Sato T and Schmid K: Hydrazinolysis of alpha-1acid glycoprotein. Biochim Biophys Acta 121: 417-420, 1966.

16. Hoshi H, Iijima H, Yagi Y, Matsunaga K, Ishihara Y and Yasuhara T: Isolation and characterization of a novel immunomodulatory $\alpha$-glucan-protein complex from the mycelium of Tricholoma matsutake in basidiomycetes. J Agric Food Chem 53: 8948-8956, 2005.

17. Janek P, Briand P and Hartman NR: The effect of estroneprogesterone treatment on cell proliferation kinetics of hormonedependent GR mouse mammary tumors. Cancer Res 35: 3698-3704, 1975

18. Hirata A, Adachi Y, Itoh W, Komoda M, Tabata K and Sugawara I: Monoclonal antibody to proteoglycan derived from Grifola frondosa (Maitake). Biol Pharm Bull 17: 539-542, 1994.

19. Ikuzawa M, Matsunaga K, Nishiyama S, et al: Fate and distribution of an antitumor protein-bound polysaccharide PSK (Krestin). Int J Immunopharmacol 10: 415-423, 1988. 